\title{
Tocopherol profile of Brazil nut oil from different geographic areas of the Amazon region
}

\author{
Mariko FUNASAKI ${ }^{1}$, Ingrid Sabino MENEZES $^{2}$, Hiléia dos Santos BARROSO 3 , \\ Sandra Patricia ZANOTTO ${ }^{4}$, Cláudia Regina Ferreira CARIOCA5
}

\begin{abstract}
The tocopherol content of Brazil nut oil from different Amazon regions (Manicoré-AM, Rio Preto da Eva-AM, São João da BalizaRR, Caroebe-RR, Belém-PA, and Xapurí-AC) was investigated by normal-phase high-performance liquid chromatography. For all authentic oils, two isomers: $\alpha$ - and $\gamma$-tocopherols were observed (37.92-74.48 $\mu \mathrm{g} \mathrm{g}^{-1}, 106.88-171.80 \mu \mathrm{g} \mathrm{g}{ }^{-1}$, respectively), and their levels were relatively constant among the oils having these geographic origins, which would enable to distinguish Brazil nut oil from other plant oils for authentication purposes. Commercial Brazil nut oils were also evaluated, and some of these oils demonstrated a tocopherol content that was very different from that of the authentic oils. Therefore, we suggest that the tocopherol profile of Brazil nut oil can be useful chemical marker for quality control and authentication.
\end{abstract}

KEYWORDS: Bertholletia excelsa H.B.K., Amazonian vegetable oil, quality control, authenticity.

\section{Perfil de tocoferol de castanha-do-Brasil de diferentes áreas geográficas da região Amazônica}

\section{RESUMO}

O teor de tocoferol de óleo de castanha-do-Brasil proveniente de diferentes regiôes da Amazônia (Manicoré-AM, Rio Preto da Eva-AM, São João da Baliza-RR, Caroebe-RR, Belém-PA e Xapurí-AC) foi investigado através de cromatografia líquida de alta eficiência em fase normal. Em todos os óleos autênticos, dois isômeros, $\alpha$ - e $\gamma$-tocoferóis $\left(37,92-74,48 \mu g^{-1}, 106,88\right.$-171,80 $\mu \mathrm{g} \mathrm{g}^{-1}$, respectivamente), foram observados, e seus níveis foram relativamente constantes em todos os óleos destas origens geográficas, o que pode distinguir o óleo de castanha-do-Brasil dos óleos de outras plantas, em termos de autenticidade. Os óleos comerciais de castanha-do-Brasil também foram avaliados e alguns mostraram teor de tocoferol muito diferente que o dos óleos autênticos. Portanto, sugere-se que o perfil de tocoferol do óleo de castanha-do-Brasil pode ser usado como marcador químico para controle de qualidade e autenticação.

PALAVRAS-CHAve: Bertholletia excelsa H.B.K., óleo vegetal da Amazônia, controle de qualidade, autenticidade.

1 Instituto Nacional de Pesquisas da Amazônia - INPA, Coordenação de Sociedade, Ambiente e Saúde, Av. André Araújo, 2936, CEP: 69060-001, Manaus-AM, Brazil. Email: marikofunasaki@gmail.com

2 Instituto Nacional de Pesquisas da Amazônia - INPA, Coordenação de Sociedade, Ambiente e Saúde, Av. André Araújo, 2936, CEP: 69060-001, Manaus-AM, Brazil. Email: ingrid_menezes17@hotmail.com

${ }^{3}$ Universidade do Estado do Amazonas - UEA, Av. Carvalho Leal, 1777, CEP: 69065-170, Manaus-AM, Brazil. Email: hileia.barroso@gmail.com

${ }^{4}$ Universidade do Estado do Amazonas - UEA, Programa de Pós-graduação em Biotecnologia e Recursos Naturais da Amazônia, Av. Carvalho Leal, 1777, CEP: 69065-170, Manaus-AM, Brazil. Email: sandrazanotto@yahoo.com.br

${ }^{5}$ Centro de Biotecnologia da Amazônia - CBA, Núcleo de Produção de Extratos, Av. Gov. Danilo de Matos Areosa, 690, CEP: 69075-351, Manaus-AM, Brazil. Email: claudiacba@gmail.com 


\section{INTRODUCTION}

The Brazil nut tree, Bertholletia excelsa H.B.K., of the family Lecythidaceae, is native to the Amazon rain forest and can reach approximately $50 \mathrm{~m}$ in height. The crunchy seed (kernel) contained in the fruit of this tree is one of the principal export commodities of northern Brazil and has been an important source of nutrients for the local residents because of the high protein (17\%) and lipid (60-70\%) content as well as the presence of minerals and vitamins that are vital for the human health (Yang 2009).

One of the characteristic components of the Brazil nut is vitamin $\mathrm{E}$, a general term for tocopherols and tocotrienols $(\alpha-, \beta-, \gamma-$, and $\delta$-), which are very effective lipid-soluble antioxidants and protect the kernels from oxidation (Gliszczyńska-Świgło and Sikorska 2004). Extensive studies on the health benefits of tocopherols have been reported (Ishihara et al. 2008; Tomé et al. 2010). Tocopherols can be biosynthesized by plants (DellaPenna and Pogson 2006) and accumulate in the edible plant oil because of their high lipophilicity (Sattler et al. 2004). The content of each isomer of vitamin E varies depending not only on the plant species (Kornsteiner et al. 2006; Cerretani et al. 2010) but also on the cultivars and environmental effects. The profiles of tocopherol and tocotrienols in the chestnut (Castanea sativa Mill.) kernels of four cultivars were evaluated, where the prevalent vitamer was $\gamma$-tocopherol, and a statistical analysis of the obtained results was also conducted to define these profiles as a reliable indicator of a specific variety (Barreira et al. 2009). Kodad et al. (2011) determined the concentration of different tocopherol homologues in almond (Prunus amygdalus Batsch) kernel oil in 17 almond cultivars. In this case, the year and location effects as well as the genotype were significant, and the authors suggested that these effects could not be explained by the temperature differences between sites, but possibly by other environmental factors such as rainfall and irrigation.

Because of an increasing demand for the quality control of natural products, detailed studies of the chemical constituents of vegetable oils, such as triacylglycerols and tocopherols, have been conducted for the purpose of authentication. Wu et al. (2004) demonstrated a distinction among commercial canola, olive, and soybean oils by means of fatty acid, di- and triacylglycerol, and tocopherol analyses using electrospray ionization Fourier transform ion cyclotron resonance mass spectrometry. Proton nuclear magnetic resonance spectroscopy was used for the geographical characterization of virgin olive oils, and the unsaponifiable fractions, which included alcohols, sterols, hydrocarbons, and tocopherols, were studied to search for potential geographical markers (Alonso-Salces et al. 2010).

Although the chemical constituents of Brazil nut oils have been described elsewhere (Lima and Gonçalves 1997; Kornsteiner et al. 2006; Yang 2009), in these cases, the Brazil nuts were primarily purchased from local markets, and there was no investigation of the constituents related to geographic or seasonal variations. Herein, we report the results of the first study to determine the tocopherol content of Brazil nut oils from different geographic areas as well as some commercial sources using normal-phase high-performance liquid chromatography (NP-HPLC). This study has relevance both in terms of health and economic importance owing to the possible use of the tocopherol profile as an authenticity marker.

\section{MATERIALS AND METHODS}

\section{Plant material and oil extraction}

Brazil nut samples were obtained from the species of Bertholletia excelsa H.B.K from different Amazon regions. The locations of the collection sites for the Brazil nuts used in the study are shown in Figure 1. The Xapurí-AC nuts were collected in April, 2011, and the other nuts were collected in the beginning of 2010. Seven authentic oils were extracted from Brazil nuts from different geographic areas in the Brazilian Amazon, namely, Manicoré-AM (two samples), Rio Preto da Eva-AM, São João da Baliza-RR, Caroebe-RR, Belém-PA, and Xapurí-AC. The samples were dried in a ventilated greenhouse at $40{ }^{\circ} \mathrm{C}$. After drying, the samples were ground in an industrial blender (METVISA model LQ4, Brusque, SC, Brazil) to a particle size of approximately 3 $\mathrm{mm}$, and then, extracted for $5 \mathrm{~h}$ with hexane (200 $\mathrm{g}$ (sample) $\mathrm{L}^{-1}$ of solvent) using a Soxhlet apparatus. In addition, five commercial oil samples were evaluated, four of which were acquired from different oleochemical suppliers and one was obtained from the local market. Therefore, a total of 12 oil samples were studied.

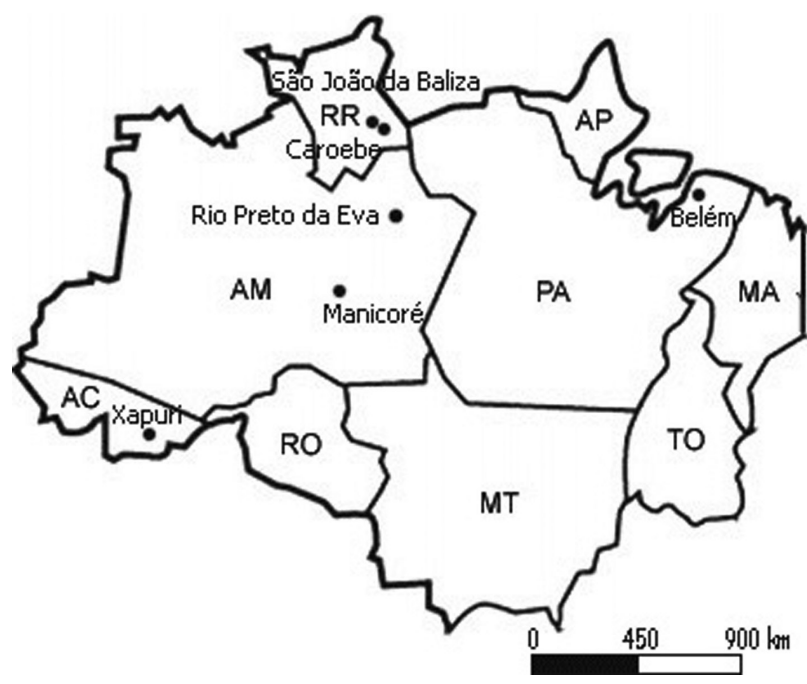

Figure 1 - Brazilian Amazon regions and the locations of the collection sites for the Brazil nuts. 


\section{Standard and sample preparation}

The extracted and commercial oils were weighed and dissolved in hexane $(10 \% \mathrm{w} / \mathrm{v})$. All of the samples were filtered into HPLC vials. Standard mixtures of the different isomers of tocopherol were prepared in hexane at concentrations within the expected ranges of the tocopherol constituents. The tocopherol standards $(\alpha-, \beta-, \gamma$-, and $\delta$-) were purchased from Calbiochem (San Diego, CA, USA). All solvents were of analytical grade.

\section{HPLC analysis}

All HPLC analyses of the tocopherols were performed on a Varian ProStar HPLC system comprising a ProStar 240 pump, a ProStar 400 autosampler, and a ProStar 310 UV-Vis detector (Varian Inc., Walnut Creek, CA, USA). The column used was a normal-phase YMC-pack SIL column $(150 \times 4.6$ $\mathrm{mm}$ id; $5 \mu \mathrm{m}$ ), equipped with a YMC-Guardpack SIL guard column $(10 \times 4.0 \mathrm{~mm}$ id; $5 \mu \mathrm{m})($ YMC Co., Kyoto, Japan). The mobile phase consisted of hexane and tetrahydrofuran (incorporating $0.25 \%$ acetic acid) with the following gradient: an initial hexane concentration of $97 \%$ was maintained for $13 \mathrm{~min}$, and then, reduced linearly to $96 \%$ over $12 \mathrm{~min}$. The conditions were as follows: flow rate, $1 \mathrm{~mL} \mathrm{~min}^{-1}$; injection volume, $50 \mu \mathrm{L}$; temperature, $24^{\circ} \mathrm{C}$; and ultraviolet detection wavelength, $295 \mathrm{~nm}$. The content of the tocopherols was determined using each standard curve and expressed as $\mu \mathrm{g}$ $\mathrm{g}^{-1}$ of oil.

\section{RESULTS}

Tocopherol content in the authentic Brazil nut oils found in the study is shown in Table 1 (upper part). The total tocopherol content was between $144.80 \mu \mathrm{g} \mathrm{g}^{-1}$ (Manicoré 2-AM) and $234.26 \mu \mathrm{g} \mathrm{g}^{-1}$ (Manicoré 1-AM). Two main tocopherols ( $\alpha$ - and $\gamma$-tocopherols) were found in all of the authentic oil samples. The content of the $\alpha$-and $\gamma$-tocopherols varied from $37.92 \mu \mathrm{g} \mathrm{g}^{-1}$ (Manicoré 2-AM) to $74.48 \mu \mathrm{g} \mathrm{g}^{-1}$ (Manicoré 1-AM) and from $106.88{\mu \mathrm{gg}^{-1}}^{-1}$ (Manicoré 2-AM) to $171.80 \mu \mathrm{g} \mathrm{g}^{-1}$ (Xapurí-AC), respectively.

Five samples of commercial Brazil nut oil were also analyzed (Table 1 , lower part). Industrial sample 1 and sample from a local market included $\alpha$ - and $\gamma$-tocopherols, while industrial samples 3 and 4 showed only $\gamma$-tocopherol, and no tocopherol was detected in industrial sample 2 .

\section{DISCUSSION}

Little variation was observed in the tocopherol content in all of the samples from the different regions, indicating that the geographic region, in this situation, does not make difference. These values are similar to those from the literature: $10-83 \mu \mathrm{g} \mathrm{g}^{-1}$ for $\alpha$-tocopherol, 79-141 $\mu \mathrm{g} \mathrm{g}^{-1}$ for $(\beta+$ $\gamma$ )-tocopherol, and 0-16 $\mu \mathrm{g} \mathrm{g}^{-1}$ for $\delta$-tocopherol (Lima and Gonçalves 1997; Kornsteiner et al. 2006; Yang 2009). Typical HPLC chromatograms of the tocopherol standards and a Brazil nut oil sample (Xapurí-AC) are shown in Figures 2 (A) and (B), respectively.

Table 1 - Tocopherol content $\left(\mu \mathrm{g} \mathrm{g}^{-1}\right)$ in Brazil nut oil from different areas of the Amazon region and the ratios of $\gamma$ - and $\alpha$-tocopherols $\left(C / C_{\alpha}\right)$.

\begin{tabular}{|c|c|c|c|c|c|c|}
\hline Region & $\alpha$-Tocopherol & $\beta$-Tocopherol & $\gamma$-Tocopherol & $\delta$-Tocopherol & Total & $\mathrm{C}_{\gamma} / \mathrm{C}_{\alpha}$ \\
\hline \multicolumn{7}{|l|}{ Authentic oils } \\
\hline Manicoré 1-AM & 74.48 & ND & 159.78 & ND & 234.26 & 2.15 \\
\hline Manicoré 2-AM & 37.92 & ND & 106.88 & ND & 144.80 & 2.82 \\
\hline Rio Preto da Eva-AM & 45.52 & ND & 115.94 & ND & 161.46 & 2.54 \\
\hline São João da Baliza-RR & 53.96 & ND & 126.23 & ND & 180.19 & 2.34 \\
\hline Caroebe-RR & 59.13 & ND & 154.51 & ND & 213.64 & 2.61 \\
\hline Belém-PA & 54.71 & ND & 129.36 & ND & 184.07 & 2.36 \\
\hline Xapurí-AC & 53.90 & ND & 171.80 & ND & 225.70 & 3.19 \\
\hline \multicolumn{7}{|l|}{ Commercial oils } \\
\hline Industry 1 & 143.02 & ND & 581.19 & ND & 724.21 & 4.06 \\
\hline Industry 2 & $N D^{a}$ & ND & $N D^{a}$ & ND & ND & - \\
\hline Industry 3 & $N D^{a}$ & ND & 182.09 & ND & 182.09 & - \\
\hline Industry 4 & $N D^{\mathrm{a}}$ & ND & 38.71 & ND & 38.71 & - \\
\hline Local market & 145.45 & ND & 149.70 & ND & 295.15 & 1.03 \\
\hline
\end{tabular}

ND: Not detected.

a Detection of tocopherols was not possible because of the presence of an interfering compound that eluted with a retention time similar to that of the target compound 

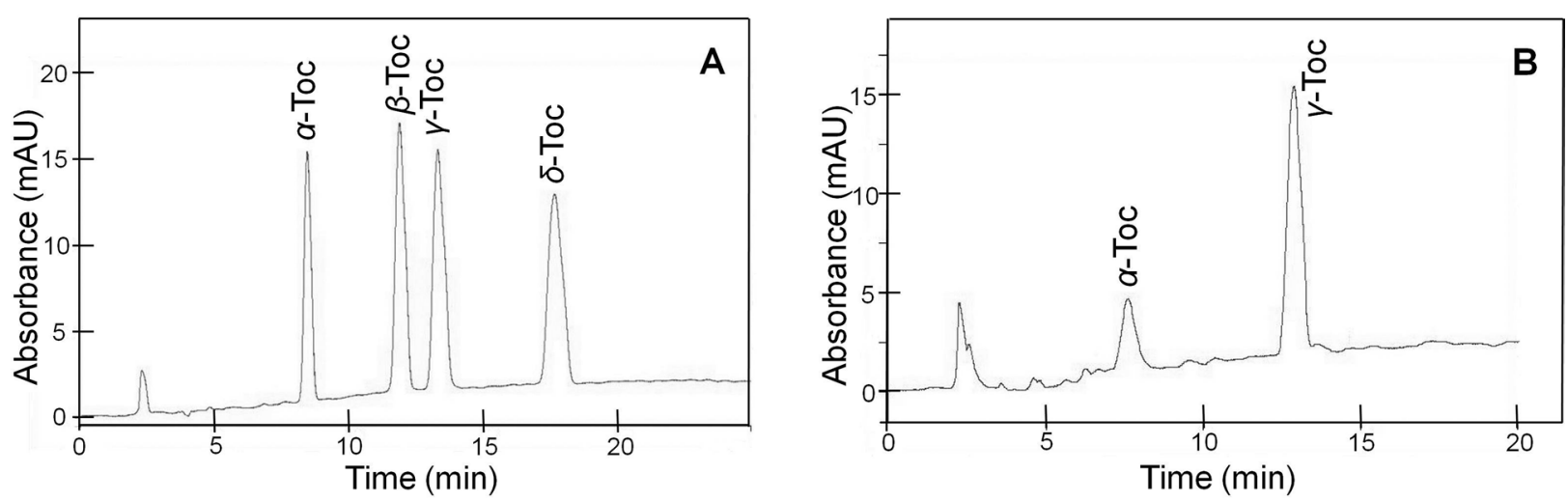

Figure 2 - HPLC Chromatograms of (A) tocopherol standards; (B) Brazil nut oil sample of Xapurí-AC. Separation conditions were described in the text. Peak identifications: $\alpha$-Toc: $\alpha$-tocopherol; $\beta$-Toc: $\beta$-tocopherol; $\gamma$-Toc: $\gamma$-tocopherol; $\delta$-Toc: $\delta$-tocopherol. mAU: milli absorbance units.

It has been reported that the tocopherol concentrations in the same species are affected by temperature in soybean (Glycine max L. Merr.) oil (Almonor et al. 1998), shea butter (a commercial seed fat of the shea tree, Vitellaria paradoxa Gaertner) (Maranz and Wiesman 2004), and olive (Olea europaea) oil (Romero et al. 2003) and by genotype, geographic location, and year in almond (Kodad et al. 2011). This is the first study which compares the tocopherol content in Brazil nuts from different geographic areas. More comprehensive studies would also be of interest, such as those pertaining to variation in samplings acquired over several years from the same location, seasonal effects (early and late harvests), and the impact of genotype (Reis et al. 2009).

The tocopherol profile of Brazil nuts can be distinguished from those of other species. The decreasing order of the relative content of each tocopherol isomer in almond, hazelnut, and olive oils is $\alpha>(\beta+\gamma)>\delta$ (or the $\delta$-isomer is not detected); that in walnuts, pistachios, pecans, and soybeans is $(\beta+\gamma)>$ $\delta>\alpha$ (or the $\alpha$-isomer is not detected); and that in peanuts is $(\beta+\gamma) \geq \alpha>\delta$ (Gliszczyńska-Świgło and Sikorska 2004; Kornsteiner et al. 2006; Cerretani et al. 2010). For Brazil nuts, the decreasing order of the relative amount of each tocopherol isomer is $\gamma>\alpha$ (a small amount of the $\delta$-isomer was detected by Lima and Gonçalves (1997) and Yang (2009)), and the ratios of the $\gamma$ - and $\alpha$-tocopherols $\left(\mathrm{C}_{\gamma} / \mathrm{C}_{\alpha}\right)$ obtained in this study did not vary significantly (Table 1 ). These findings indicate that the tocopherol profile is useful for distinguishing Brazil nut oil from other vegetable oils.

In the HPLC chromatograms of industrial samples 2, 3, and 4 , the occurrence of an interface (extremely wide peak) was observed at the retention time for $\alpha$ - and/or $\gamma$-tocopherol, and therefore, the quantification of these tocopherols was not possible. This may be due to the different processing conditions used for commercial oils, such as the method of extraction or purification. In the laboratory, the oils were extracted by solvents. On the other hand, in industry, the Brazil nut oil is extracted by cold pressing followed by filtering (Souza and Menezes 2004), and then, the oil may be refined, bleached, and deodorized, and antioxidants or other additives may be incorporated depending on the industrial requirements. To clarify whether the differences arise as a result of the isolation method, authentic oils prepared by cold pressing should be compared with those acquired by solvent extraction. In addition, the ratio of $\gamma$ - and $\alpha$-tocopherols $\left(\mathrm{C}_{\gamma} /\right.$ $\mathrm{C}_{\alpha}$ ) in the oils from industrial sample 1 and the sample from a local market (4.06 and 1.03, respectively) were different from those in the authentic oils (2.15-3.18). This difference may also be attributed to certain industrial practices, including the addition of tocopherols from other sources to prevent oil oxidation.

In conclusion, variation in the tocopherol content of Brazil nut oil based on geographic origin was not exceptional, and with further investigation, the tocopherol profile can be used as a marker for authenticity of the oil and the detection of adulteration.

\section{ACKNOWLEDGEMENT}

The authors would like to thank Brazilian oleochemical industries, Embrapa (Project Kamukaia), and particularly Dr. Habdel Nasser Rocha da Costa, Federal University of Roraima, for providing samples. This work was financially supported by the Conselho Nacional de Desenvolvimento Científico e Tecnológico (CNPq), and INCT/CEAB.

\section{REFERENCES}

Almonor, G.O.; Fenner, G.P.; Wilson, R.F. 1998. Temperature effects on tocopherol composition in soybeans with genetically improved oil quality. Journal of the American Oil Chemists' Society, 75: 591-596.

Alonso-Salces, R.M.; Héberger, K.; Holland, M.V.; Moreno-Rojas, J.M.; Mariani, C.; Bellan, G.; Reniero, F.; Guillou, C. 2010. Multivariate analysis of NMR fingerprint of the unsaponifiable 
fraction of virgin olive oils for authentication purposes. Food Chemistry, 118: 956-965.

Barreira, J.C.M.; Alves, R.C.; Casal, S.; Ferreira, I.C.F.R.; Oliveira, M.B.P.P.; Pereira, J.A. 2009. Vitamin E profile as a reliable authenticity discrimination factor between chestnut (Castanea sativa Mill.) cultivars. Journal of Agricultural and Food Chemistry, 57: 5524-5528.

Cerretani, L.; Lerma-García, M.J.; Herrero-Martínez, J.M.; Gallina-Toschi, T.; Simó-Alfonso, E.F. 2010. Determination of tocopherols and tocotrienols in vegetable oils by nanoliquid chromatography with ultraviolet-visible detection using a silica monolithic column. Journal of Agricultural and Food Chemistry, 58: 757-761.

DellaPenna, D.; Pogson, B.J. 2006. Vitamin synthesis in plants: tocopherols and carotenoids. Annual Review of Plant Biology, 57: 711-738.

Gliszczyńska-Świgło, A.; Sikorska, E. 2004. Simple reversed-phase liquid chromatography method for determination of tocopherols in edible plant oils. Journal of Chromatography A, 1048: 195-198.

Ishihara, M.; Kojima, R.; Ito, M. 2008. Influence of aging on gastric ulcer healing activities of the antioxidants $\alpha$-tocopherol and probucol. European Journal of Pharmacology, 601: 143-147.

Kodad, O.; Estopañán, G.; Juan, T.; Mamouni, A. 2011. Tocopherol concentration in almond oil: Genetic variation and environmental effects under warm conditions. Journal of Agricultural and Food Chemistry, 59: 6137-6141.

Kornsteiner, M.; Wagner, K.-H.; Elmadfa, I. 2006. Tocopherols and total phenolics in 10 different nut types. Food Chemistry, 98: 381-387.

Lima, J.R.; Gonçalves, L.A.G. 1997. Quantificação de tocoferóis em óleo de milho, soja, castanha-do-pará e castanha de caju por cromatografia líquida de alta eficiência em fase reversa. Alimentos e Nutrição Araraquara, 8: 65-73.
Maranz, S.; Wiesman, Z. 2004. Influence of climate on the tocopherol content of shea butter. Journal of Agricultural and Food Chemistry, 52: 2934-2937.

Reis, A.M.M.; Braga, A.C.; Lemes, M.R.; Gribel, R.; Collevatti, R.G. 2009. Development and characterization of microsatellite markers for the Brazil nut tree Bertholletia excelsa Humb. \& Bonpl. (Lecythidaceae). Molecular Ecology Resources, 9: 920-923.

Romero, M.P.; Tovar, M.J.; Ramo, T.; Motilva, M.J. 2003. Effect of crop season on the composition of virgin olive oil with protected designation of origin "Les Garrigues". Journal of the American Oil Chemists' Society, 80: 423-430.

Sattler, S.E.; Gillilanda, L.U.; Magallanes-Lundbacka, M.; Pollardb, M.; DellaPennaa, D. 2004. Vitamin E is essential for seed longevity and for preventing lipid peroxidation during germination. The Plant Cell, 16: 1419-1432.

Souza, M.K.; Menezes, H.C. 2004. Processamento de Amêndoa e torta de Castanha-do-Brasil e farinha de mandioca: parâmetros de qualidade. Ciência e Tecnologia de Alimentos, 21: 120-128.

Tomé, A.R.; Ferreira, P.M.P.; Freitas, R.M. 2010. Inhibitory action of antioxidants (ascorbic acid or $\alpha$-tocopherol) on seizures and brain damage induced by pilocarpine in rats. Arquivos de NeuroPsiquiatria, 68: 355-361.

Wu, Z.; Rodgers, R.P.; Marshall, A.G. 2004. Characterization of vegetable oils: Detailed compositional fingerprints derived from electrospray ionization fourier transform ion cyclotron resonance mass spectrometry. Journal of Agricultural and Food Chemistry, 52: $5322-5328$

Yang, J. 2009. Brazil nuts and associated health benefits: A review. LWT - Food Science and Technology, 42: 1573-1580.

Recebido em: 17/05/2012

Aceito em: 06/12/2012 
